\title{
PELO Gene
}

National Cancer Institute

\section{Source}

National Cancer Institute. PELO Gene. NCI Thesaurus. Code C104581.

This gene may be involved in cell division and RNA degradation. 